\title{
EFFECT OF QUANTITY AND METHOD OF APPLICATION OF SULPHUR AT DIFFERENT GROWTH STAGES IN IMPROVING THE QUALITY OF QPM AND NUTRIENT AVAILABILITY IN THE SOIL
}

\author{
NAVATHA. $\mathbf{N}^{1}$, VANI. K. $\mathbf{P}^{2}$, SRINIVAS. $\mathrm{A}^{3}$ \& SURENDRA BABU. $\mathrm{P}^{4}$ \\ ${ }^{1,2,3}$ Professor, Department of Agronomy, Professor Jayashankar Telangana State \\ Agricultural University, Rajendranagar, Hyderabad, India \\ ${ }^{4}$ Department of Soil Science and chemistry, Professor Jayashankar Telangana State
}

Agricultural University, Rajendranagar, Hyderabad, India

\begin{abstract}
In order to investigate the effect of sulphur levels and method of application on sulphur uptake in quality protein maize (QPM) at 30, 60, 90 and harvest stage (grain and stover) and available nutrients in soil, an experiment was conducted. This experiment was conducted with factorial arrangement based on randomised block design with three replications, four factors of sulphur levels $\left(S_{1}:-10 \mathrm{~kg} \mathrm{ha}^{-1}, S_{2}:-20 \mathrm{~kg} \mathrm{ha}^{-1}, S_{3}:-30 \mathrm{~kg} \mathrm{ha}^{-1}\right.$ and $\left.S_{4}:-40 \mathrm{~kg} \mathrm{ha}^{-1}\right)$ and two method of sulphur application ( $M_{1}:$ 100\% basal as single dose; $M_{2}$ : Two split applications: - 50\% each at basal and knee height stage) in Quality Protein Maize (QPM) production in an experimental field located at the College farm, Professor Jayashankar Telangana State Agricultural University, Rajendranagar, Hyderabad, India. The result of experiment showed that the sulphur uptake increased progressively with sulphur levels. Among the four sulphur levels, significantly higher sulphur uptake was observed with $40 \mathrm{~kg} \mathrm{~S} \mathrm{ha-1.} \mathrm{In} \mathrm{method} \mathrm{of} \mathrm{application,} \mathrm{sulphur} \mathrm{uptake} \mathrm{was} \mathrm{found} \mathrm{superior} \mathrm{in}$ split application at basal and at knee height stage, compared to basal application of sulphur at 30, 60, 90 DAS at harvest stage. The application of sulphur had not shown any significant effect on the available nitrogen, phosphorous and potassium status of the soil. Sulphur status in the soil increased from its initial condition in all the treatments, with increase in sulphur levels. However, the available sulphur content in soil significantly increased in the treatment applied with $40 \mathrm{~kg} \mathrm{~S} \mathrm{hal}^{-1}$ and the lowest with $10 \mathrm{~kg} \mathrm{~S} \mathrm{ha-1.} \mathrm{The} \mathrm{available} \mathrm{sulphur} \mathrm{content} \mathrm{in} \mathrm{soil} \mathrm{varied} \mathrm{from} \mathrm{its} \mathrm{initial} \mathrm{status} \mathrm{in}$ different time of application of sulphur.
\end{abstract}

KEYWORDS: Available, Nutrients, Soil, Sulphur, Uptake \& Quality Protein Maize

Received: Jun 21, 2017; Accepted: Jul 15, 2017; Published: Aug 07, 2017; Paper Id.: IJASRAUG201788

\section{INTRODUCTION}

Maize (Zea mays L.) is an important feed and food crop after wheat and rice, and ranks third in the world and also in India. It is known as a most important profitable crop of great agro-financial value. It is grown widely in subtropical, tropical and temperate region in the world.

Maize is an exhaustive crop that absorbs huge quantity of nutrient from the soil during different stages of growth. Sulphur is an essential nutrient for animal and all plant life. Plant takes up approximately the same amount of sulphur as that of phosphorus (Tandon, 1991). Sulphur importance is increasing in all regions of the world and in some areas, it is second to nitrogen in importance. Sulphur deficiencies are occurring with greater frequency in more locations throughout the world. As a result of its importance, many agriculturists are now classifying it as 
fourth major nutrient.

Sulphur is essential for synthesis of the amino acids, a component of vitamin A and activates certain enzyme systems in plants (Havlin., 2004). Under S deficient conditions, the efficiency of applied NPK fertilizers may be seriously affected and crop yield levels may not be sustainable (Ahmad., 1994). Continuous removal of S from soils through plant uptake has led to widespread S deficiency and affected soil S budget (Aulakh., 2003) all over the world. It was reported that sugar crops yield increase at $60 \mathrm{Kg}$ ha-1 sulphur application in the form of gypsum and observed residual effects on the growth of the ratoon crop (Mathew., 2003). Fertilizers, which contain sulphur as a combining ingredient, are being replaced with high analysis fertilizers that are low in sulphur. S fertilization increases oil, protein and glucosinolate in seed (Malhi., 2007). Nitrogen use efficiency also improves with S and thus maintains adequate fatty acid quality and oil level (Fismes., 2000). Sulphur deficiency has become a major constraint in crop production in coarse textured soils (Takkar., 1989). Introduction of high yielding crop varieties, intensive and multiple cropping and the decreased use of farmyard manures seem to have lead to a wide occurrence of S deficiency. Sulphur deficiency has been reported from over 70 countries worldwide (Tandon., 1991). Crop yield and quality can be effected with inadequate S supply as S is necessary for the structure of methionine and cystein, protein certain amino acids, and enzyme synthesis.

Updating of sulphur recommendation to maize is currently focused, therefore, it would be a very opportune time to look at split applications of sulphur, to determine if timing should be considered for farmers growing maize. In general practice, sulphur is applied in a single basal dose, while $\mathrm{N}$ is applied in two split doses. This application practice may create an imbalance between $\mathrm{S}$ and $\mathrm{N}$ at later growth stages as more than $50 \%$ of sulphur applied to soil may leach out, because of the strong leaching behaviour of sulphate like nitrate. (Ahmad et al., 1998). In view of this fact, the present study was designed to assess the effect of different sulphur levels and method of application on sulphur uptake by dry matter, grain and available nutrients in soil.

\section{MATERIAL AND METHODS}

\section{Experimental Site, Climate and Soil}

The field experiment entitled "Studies on sulphur levels and method of application on sulphur uptake at 30, 60, 90 DAS and at harvest stage in QPM and available nutrients in soil after harvest" was conducted at College farm, Professor Jayashankar Telangana State Agricultural University, Rajendranagar, Hyderabad situated at $17^{\circ} 19^{\prime} \mathrm{N}$ latitude and $78^{\circ} 23^{\prime}$ E longitude at an altitude of $542.3 \mathrm{~m}$ above mean sea level. The experimental soil was sandy loam in texture, neutral in reaction, low in organic carbon, available nitrogen and sulphur, medium in available phosphorous and high in potassium. Experiment was carried out with four sulphur levels $\left(S_{1}: 10 \mathrm{~kg} \mathrm{ha}^{-1}, \mathrm{~S}_{2}: 20 \mathrm{~kg} \mathrm{ha}^{-1}, \mathrm{~S}_{3}: 30 \mathrm{~kg} \mathrm{ha}^{-1}\right.$ and $\left.\mathrm{S}_{4}: 40 \mathrm{~kg} \mathrm{ha}^{-1}\right)$ as first factor and method of sulphur application $\left(\mathrm{M}_{1}: 100 \%\right.$ basal as single dose; $\mathrm{M}_{2}$ : Two split applications:-50\% each at basal and knee height stage) as second factor, comprising eight treatment combination, laid out in randomized block design with factorial concept replicated thrice.

Quality protein maize hybrid (HQPM-1) was sown in kharif- 2014 at a spacing of $60 \mathrm{~cm} \times 20 \mathrm{~cm}$. A uniform dose of $80 \mathrm{~kg} \mathrm{P}_{2} \mathrm{O}_{5}$ as diammonium phosphate, potassium @ $80 \mathrm{~kg} \mathrm{ha}^{-1}$ as murate of potash was applied to all the treatments. Entire dose of phosphorous and half of potassium were applied at the time of sowing. Nitrogen was applied as per the treatments through urea in three equal splits (at basal, knee-height and tasseling stages). Similarly, the remaining potassium and nitrogen was top dressed at tasseling stage. Sulphur was applied through gypsum in two methods of applications i.e. $\mathrm{M}_{1^{-}}-100 \%$ basal application at time of sowing; $\mathrm{M}_{2}$ - two split applications:-50\% each at basal and knee height stage as per 
the treatments.

\section{RESULTS AND DISCUSSIONS}

\section{Sulphur Uptake in Plant at 30, 60, 90 DAS}

The data pertaining to sulphur uptake at 30,60,90 DAS in the plant was significantly influenced by levels and method of application of sulphur, as shown in Table 1.

Sulphur uptake in plant at 30, 60, 90 DAS was significantly increased with increasing levels of sulphur from 10 $\mathrm{kg} \mathrm{S} \mathrm{ha}{ }^{-1}$ to $40 \mathrm{~kg} \mathrm{~S} \mathrm{ha}^{-1}$. At $30 \mathrm{DAS}$, sulphur uptake was significantly influenced by sulphur levels. Among the four


uptake by $30 \mathrm{~kg} \mathrm{~S} \mathrm{ha}^{-1}\left(7.16 \mathrm{~kg} \mathrm{ha}^{-1}\right)$, while lower sulphur uptake of $6.86 \mathrm{~kg} \mathrm{ha}^{-1}$ recorded with $10 \mathrm{~kg}$ sulphur application. Sulphur uptake by plant was non-significant among the method of application at early stages of crop growth.

Similarly, at 60 DAS, sulphur uptake was significantly influenced by sulphur levels, where maximum sulphur uptake (13.3 $\left.\mathrm{kg} \mathrm{ha}^{-1}\right)$ was observed with $40 \mathrm{~kg} \mathrm{~S} \mathrm{ha}^{-1}$ followed by $30 \mathrm{~kg} \mathrm{ha}^{-1}\left(12.9 \mathrm{~kg} \mathrm{ha}^{-1}\right)$ and minimum sulphur uptake of $11.9 \mathrm{~kg} \mathrm{ha}^{-1}$ was noticed with $10 \mathrm{~kg}$ sulphur application. Split application of sulphur i.e. $50 \%$ as basal and $50 \%$ at $\mathrm{knee}$ height stage resulted in maximum sulphur uptake $\left(12.8 \mathrm{~kg} \mathrm{ha}^{-1}\right)$ at $60 \mathrm{DAS}$, followed by $100 \%$ basal application of sulphur $\left(12.5 \mathrm{~kg} \mathrm{ha}^{-1}\right)$.

The data at 90 DAS on sulphur uptake revealed that, as the crop advanced to 90 days, the sulphur uptake increased progressively with sulphur levels. Among the four sulphur levels, significantly higher sulphur uptake of $16.6 \mathrm{~kg}$ $\mathrm{ha}^{-1}$ was observed with $40 \mathrm{~kg} \mathrm{~S} \mathrm{ha}^{-1}$, significantly superior over the sulphur uptake obtained with $30 \mathrm{~kg} \mathrm{~S}^{-1}$ (16.2 kg ha $\left.{ }^{1}\right), 20 \mathrm{~kg} \mathrm{~S} \mathrm{ha}^{-1}\left(15.8 \mathrm{~kg} \mathrm{ha}^{-1}\right)$ and $10 \mathrm{~kg} \mathrm{~S} \mathrm{ha}^{-1}\left(15.4 \mathrm{~kg} \mathrm{ha}^{-1}\right)$. In method of application, sulphur uptake was found superior in split application as basal and at knee height stage $\left(16.1 \mathrm{~kg} \mathrm{ha}^{-1}\right)$ compared to basal application of sulphur (15.8 kg ha $\left.{ }^{-1}\right)$ at 90 DAS.

\section{Sulphuruptake by Grain and Stover at Harvest Stage}

The data pertaining to sulphur uptake by grain and stover was significantly influenced by levels and method of application of sulphur as shown in Table 2 .

Sulphur uptake increased with increased levels of sulphur. Application of $40 \mathrm{~kg} \mathrm{~S}^{-1} \mathrm{had}^{-1}$ recorded significantly more sulphur uptake $\left(12.1 \mathrm{~kg} \mathrm{ha}^{-1}\right)$ by grain, followed by $30 \mathrm{~kg} \mathrm{ha}^{-1}\left(10.1 \mathrm{~kg} \mathrm{ha}^{-1}\right), 20 \mathrm{~kg} \mathrm{ha}^{-1}\left(9.30 \mathrm{~kg} \mathrm{ha}^{-1}\right)$ and minimum sulphur uptake obtained with $10 \mathrm{~kg} \mathrm{~S} \mathrm{ha}^{-1}\left(8.65 \mathrm{~kg} \mathrm{ha}^{-1}\right)$. The per cent increase in sulphur uptake was $7.5 \%, 16.7 \%$ and $39.8 \%$ with $20 \mathrm{~kg} \mathrm{ha}^{-1}, 30 \mathrm{~kg} \mathrm{ha}^{-1}$ and $40 \mathrm{~kg} \mathrm{ha}^{-1}$ over $10 \mathrm{~kg} \mathrm{ha}^{-1}$.

Higher sulphur uptake recorded by stover $\left(9.46 \mathrm{~kg} \mathrm{ha}^{-1}\right)$ with $40 \mathrm{~kg} \mathrm{~S} \mathrm{ha}^{-1}$, followed by $30 \mathrm{~kg} \mathrm{ha}^{-1}\left(8.70 \mathrm{~kg} \mathrm{ha}^{-1}\right), 20$ $\mathrm{kg} \mathrm{ha}^{-1}\left(8.01 \mathrm{~kg} \mathrm{ha}^{-1}\right)$ and lower sulphur uptake obtained with $10 \mathrm{~kg} \mathrm{~S} \mathrm{ha}^{-1}\left(7.20 \mathrm{~kg} \mathrm{ha}^{-1}\right)$ by stover. The per cent of sulphur uptake was higher with $40 \mathrm{~kg} \mathrm{~S} \mathrm{ha}^{-1}(31.3 \%)$, followed by $30 \mathrm{~kg} \mathrm{~S}^{-1}(20.8 \%)$ and $20 \mathrm{~kg} \mathrm{~S}^{-1}$ (11.2\%), compared to when maize plants were applied with $10 \mathrm{~kg} \mathrm{~S} \mathrm{ha}^{-1}$.

Similarly, among different method of application, split application of sulphur as $50 \%$ as basal and $50 \%$ at knee heigh stage $\left(\mathrm{M}_{2}\right)$ showed significant effect on sulphur uptake, indicating increased sulphur uptake $\left(10.4 \mathrm{~kg} \mathrm{ha}^{-1}\right)$ by grain and $\left(8.69 \mathrm{~kg} \mathrm{ha}^{-1}\right)$ by stover, significantly higher than $\left(\mathrm{M}_{1}\right)$ basal application $\left(9.65 \mathrm{~kg} \mathrm{ha}^{-1}\right)$ by grain and $\left(8 \mathrm{~kg} \mathrm{ha}^{-1}\right)$ by stover. 
Interaction effect between levels and method of application of sulphur was found non-significant on the sulphur uptake of quality protein maize hybrid.

Application of sulphur significantly increased the sulphur uptake by maize grain and stover. Increase in sulphur uptake may be attributed to increase in $\mathrm{S}$ concentration in plant and dry matter yield Sakal et al., 2000 and Srinivasraoet al., 2010.

Split application of sulphur $(50 \% \mathrm{~S}$ at sowing $+50 \% \mathrm{~S}$ top dressed at knee height stage) was more effective for improving plant sulphur nutrient status, i.e. increasing S accumulation and concentration in shoot and maize kernel. These results are in conformity with the findings of Habtegebrial and Singh 2006 and Wang et al. (2014).

\section{POST- HARVEST SOIL ANALYSIS}

\section{Available N, P and K}

Results pertaining to available nitrogen, phosphorous and potassium in soil after harvest of the crop was not significantly influenced by levels and method of application of sulphur. Interaction effect of levels and method of application of sulphur in quality protein maize was also found to be non- significant as presented in the Table 3.

The application of sulphur had not shown any significant effect on the available nitrogen, phosphorous and potassium status of the soil. These results are also in line with the findings of Ramanathan and Ramanathan (1985).

\section{Available Sulphur}

The available sulphur content in soil after harvest of quality protein maize was analysed statistically and represented in table 3. Sulphur status in the soil increased from its initial condition in all the treatments, with increase in sulphur levels. However, the available sulphur content in soil significantly increased in the treatment applied with $40 \mathrm{~kg} \mathrm{~S}$ $\mathrm{ha}^{-1}\left(12.5 \mathrm{~kg} \mathrm{ha}^{-1}\right)$ and the lowest with $10 \mathrm{~kg} \mathrm{~S} \mathrm{ha}^{-1}\left(10.7 \mathrm{~kg} \mathrm{ha}^{-1}\right)$.

At harvest stage, the available sulphur content in soil varied from its initial status in different time of application of sulphur. However, significantly higher available sulphur content (11.8 $\left.\mathrm{kg} \mathrm{ha}^{-1}\right)$ in soil after harvest of the crop was shown in the $\mathrm{M}_{2}$ treatment i.e. split application of sulphur as basal and at knee height stage compared to lower sulphur status in the soil, after harvest of the crop $\left(11.4 \mathrm{~kg} \mathrm{ha}^{-1}\right.$ ) with $\mathrm{M}_{1}$ (basal application) of sulphur.

Interaction effect between levels and method of application of sulphur was found non-significant with the available sulphur in soil after harvest of the crop. Increased levels of sulphur influenced the sulphur status in the soil. Similar results were found by Mahesh (2001) and Choudhary et al. (2013).

\section{CONCLUSIONS}

It is concluded based on the above findings, in respect of the sulphur uptake by QP Maize at 30, 60, 90 and harvest stages that, the best results were achieved with application of sulphur @ $40 \mathrm{~kg} \mathrm{ha}^{-1}$ along with split method of application. Hence, it can be recommended for sustaining nutrient availability in quality protein maize.

Table 1: Sulphur Uptake $\left(\mathrm{kg} \mathrm{ha}^{-1}\right)$ by Plant of QPM as Influenced by Sulphur Levels and Method of Application

\begin{tabular}{|l|c|c|c|c|c|c|c|c|c|}
\hline & \multicolumn{3}{|c|}{ 30DAS } & \multicolumn{3}{c|}{ 60 DAS } & \multicolumn{3}{c|}{ DAS } \\
\hline Sulphur Levels (S) & Basal $\left(\mathbf{M}_{\mathbf{1}}\right)$ & Split $\left(\mathbf{M}_{\mathbf{2}}\right)$ & Mean & Basal $\left(\mathbf{M}_{\mathbf{1}}\right)$ & Split $\left(\mathbf{M}_{\mathbf{2}}\right)$ & Mean & Basal $\left(\mathbf{M}_{\mathbf{1}}\right)$ & Split $\left(\mathbf{M}_{2}\right)$ & $\mathbf{M e a n}$ \\
\hline $\mathbf{S}_{\mathbf{1}}: \mathbf{1 0} \mathbf{~ k g ~ h a}^{-\mathbf{1}}$ & 6.97 & 6.76 & $\mathbf{6 . 8 6}$ & 11.9 & 12.0 & $\mathbf{1 1 . 9}$ & 15.3 & 15.6 & $\mathbf{1 5 . 4}$ \\
\hline $\mathbf{S}_{\mathbf{2}} \mathbf{:} \mathbf{2 0} \mathbf{~ k g ~ h a}^{-\mathbf{1}}$ & 7.10 & 7.00 & $\mathbf{7 . 0 5}$ & 12.3 & 12.6 & $\mathbf{1 2 . 4}$ & 15.7 & 15.9 & $\mathbf{1 5 . 8}$ \\
\hline
\end{tabular}




\begin{tabular}{|c|c|c|c|c|c|c|c|c|c|}
\hline \multicolumn{10}{|c|}{ Table 1: Contd., } \\
\hline$S_{3}: 30 \mathrm{~kg} \mathrm{ha}^{-1}$ & 7.23 & 7.10 & 7.16 & 12.7 & 13.1 & 12.9 & 16.0 & 16.4 & 16.2 \\
\hline$S_{4}: 40 \mathrm{~kg} \mathrm{ha}^{-1}$ & 7.33 & 7.22 & 7.27 & 13.2 & 13.5 & 13.3 & 16.4 & 16.7 & 16.6 \\
\hline Mean & 7.16 & 7.02 & & 12.5 & 12.8 & & 15.8 & 16.1 & \\
\hline & SEm \pm & $\mathrm{CD}(\mathrm{p}=0.05)$ & & SEm \pm & $\mathrm{CD}(\mathrm{p}=0.05)$ & & SEm \pm & $\mathrm{CD}(\mathrm{p}=0.05)$ & \\
\hline $\mathrm{S}$ & 0.08 & 0.23 & & 0.12 & 0.35 & & 0.12 & 0.35 & \\
\hline $\mathrm{M}$ & 0.06 & NS & & 0.09 & 0.26 & & 0.08 & 0.23 & \\
\hline $\mathrm{S} \times \mathrm{M}$ & 0.12 & NS & & 0.18 & NS & & 0.17 & NS & \\
\hline
\end{tabular}

$\mathrm{M}_{1}: 100 \%$ basal application; $\quad \mathrm{M}_{2}: 50 \%$ basal+50\% at knee heigh stage

Table 2: Sulphur Uptake ( $\left.\mathrm{kg} \mathrm{ha}^{-1}\right)$ by Grain and Stoverof QPM as Influenced by Sulphur Levels and Method of Application

\begin{tabular}{|l|c|c|c|c|c|c|}
\hline & \multicolumn{3}{|c|}{ Grain } & \multicolumn{3}{c|}{ Stover } \\
\hline Sulphur Levels (S) & Basal $\left(\mathbf{M}_{\mathbf{1}}\right)$ & Split $\left(\mathbf{M}_{\mathbf{2}}\right)$ & Mean & Basal $\left(\mathbf{M}_{\mathbf{1}}\right)$ & Split $\left(\mathbf{M}_{\mathbf{2}}\right)$ & Mean \\
\hline $\mathbf{S}_{\mathbf{1}}: \mathbf{1 0} \mathbf{~ k g ~ h a}^{-1}$ & 8.06 & 9.23 & $\mathbf{8 . 6 5}$ & 6.60 & 7.80 & $\mathbf{7 . 2 0}$ \\
\hline $\mathbf{S}_{\mathbf{2}}: \mathbf{2 0} \mathbf{~ k g ~ h a}^{-1}$ & 8.83 & 9.76 & $\mathbf{9 . 3 0}$ & 7.70 & 8.33 & $\mathbf{8 . 0 1}$ \\
\hline $\mathbf{S}_{\mathbf{3}}: \mathbf{3 0} \mathbf{~ k g ~ h a}^{-1}$ & 10.0 & 10.2 & $\mathbf{1 0 . 1}$ & 8.46 & 8.93 & $\mathbf{8 . 7 0}$ \\
\hline $\mathbf{S}_{\mathbf{4}}: \mathbf{4 0} \mathbf{~ k g ~ h a}^{-1}$ & 11.7 & 12.5 & $\mathbf{1 2 . 1}$ & 9.23 & 9.70 & $\mathbf{9 . 4 6}$ \\
\hline Mean & $\mathbf{9 . 6 5}$ & $\mathbf{1 0 . 4}$ & & $\mathbf{8 . 0 0}$ & $\mathbf{8 . 6 9}$ & \\
\hline & $\mathrm{SEm} \pm$ & $\mathrm{CD}(\mathrm{p}=0.05)$ & & $\mathrm{SEm} \pm$ & $\mathrm{CD}(\mathrm{p}=0.05)$ & \\
\hline $\mathrm{S}$ & 0.30 & 0.88 & & 0.22 & 0.63 & \\
\hline $\mathrm{M}$ & 0.20 & 0.61 & & 0.15 & 0.43 & \\
\hline $\mathrm{S} \times \mathrm{M}$ & 0.43 & $\mathrm{NS}$ & & 0.31 & $\mathrm{NS}$ & \\
\hline
\end{tabular}

$\mathrm{M}_{1}: 100 \%$ basal application; $\mathrm{M}_{2}: 50 \%$ basal+50\% at knee heigh stage

Table 3: Available $\mathrm{N}, \mathrm{P}_{2} \mathrm{O}_{5}, \mathrm{~K}_{2} \mathrm{O}\left(\mathrm{kg} \mathrm{ha}^{-1}\right)$ and $\mathrm{S}\left(\mathrm{mg} \mathrm{kg}^{-1}\right)$ in Soil after Harvest of the Crop Influenced by Sulphur Levels and Method of Application

\begin{tabular}{|c|c|c|c|c|c|c|c|c|c|c|c|c|}
\hline \multirow[b]{2}{*}{$\begin{array}{c}\text { Sulphur } \\
\text { levels (S) }\end{array}$} & \multicolumn{3}{|c|}{ Available $\mathrm{N}$} & \multicolumn{3}{|c|}{ Available $\mathrm{P}_{2} \mathrm{O}_{5}$} & \multicolumn{3}{|c|}{ Available $\mathrm{K}_{2} \mathrm{O}$} & \multicolumn{3}{|c|}{ Available S } \\
\hline & $\begin{array}{c}\text { Basal } \\
\left(M_{1}\right)\end{array}$ & $\begin{array}{l}\text { Split } \\
\left(\mathbf{M}_{2}\right)\end{array}$ & Mean & $\begin{array}{c}\text { Basal } \\
\left(M_{1}\right)\end{array}$ & $\begin{array}{l}\text { Split } \\
\left(\mathbf{M}_{2}\right)\end{array}$ & Mean & $\begin{array}{c}\text { Basal } \\
\left(\mathrm{M}_{1}\right)\end{array}$ & $\begin{array}{l}\text { Split } \\
\left(\mathbf{M}_{2}\right)\end{array}$ & Mean & $\begin{array}{l}\text { Basal } \\
\left(\mathrm{M}_{1}\right)\end{array}$ & Split $\left(\mathbf{M}_{2}\right)$ & Mean \\
\hline $\begin{array}{l}S_{1}: 10 \mathrm{~kg} \\
\mathrm{ha}^{-1}\end{array}$ & 276 & 282 & 279 & 39.3 & 39.6 & 39.5 & 374 & 375 & 374 & 10.5 & 10.9 & 10.7 \\
\hline $\begin{array}{l}\mathrm{S}_{2}: 20 \mathrm{~kg} \\
\mathrm{ha}^{-1}\end{array}$ & 285 & 288 & 287 & 40.0 & 40.5 & 40.2 & 375 & 375 & 375 & 11.0 & 11.5 & 11.2 \\
\hline $\begin{array}{l}S_{3}: 30 \mathrm{~kg} \\
\mathrm{ha}^{-1}\end{array}$ & 290 & 293 & 292 & 40.7 & 40.8 & 40.8 & 376 & 377 & 376 & 11.8 & 12.0 & 11.9 \\
\hline $\begin{array}{l}\mathrm{S}_{4}: 40 \mathrm{~kg} \\
\mathrm{ha}^{-1}\end{array}$ & 295 & 300 & 297 & 41.0 & 41.6 & 41.3 & 377 & 378 & 377 & 12.2 & 12.8 & 12.5 \\
\hline Mean & 287 & 291 & & 40.3 & 40.6 & & 375 & 376 & & 11.4 & 11.8 & \\
\hline & $\mathrm{SEm} \pm$ & $\begin{array}{c}C D \\
(p=0.05)\end{array}$ & & $\mathrm{SEm} \pm$ & $\begin{array}{c}C D \\
(p=0.05)\end{array}$ & & $\mathrm{SEm} \pm$ & $\begin{array}{c}C D \\
(p=0.05)\end{array}$ & & $\mathrm{SEm} \pm$ & $\begin{array}{c}C D \\
(p=0.05)\end{array}$ & \\
\hline $\mathrm{S}$ & 7.56 & NS & & 2.33 & NS & & 13.7 & NS & & 0.13 & 0.38 & \\
\hline $\mathrm{M}$ & 5.35 & NS & & 1.66 & NS & & 9.7 & NS & & 0.09 & 0.26 & \\
\hline $\mathrm{S} \times \mathrm{M}$ & 10.7 & NS & & 3.33 & NS & & 19.4 & NS & & 0.18 & NS & \\
\hline
\end{tabular}

$\mathrm{M}_{1}: 100 \%$ basal application; $\mathrm{M}_{2}: 50 \%$ basal $+50 \%$ at knee heigh stage

\section{REFERENCES}

1. Ahmad, A.G., Abrol, Y.P and Abdin, M.Z. 1998. Effect of split application of sulphur and nitrogen on growth and yield attributes of Brassica genotype differing in time of flowering. Canadian Journal of Plant Science. 181: 193-199.

2. Ahmad, N., Saleem, M.T., Rashid, M and Jalil, A. 1994. Sulphur status and crop response in Pakistan soils. National Fertilizer Development Center. Publications No. 7/94. Planning and Development Division. Islamabad. pp.1-5.

3. Aulakh, M.S., Jaggi, R.C and Sharma, R. 2002. Mineralization-immobilization of soil organic S and oxidation of elemental $S$ in subtropical soils under flooded and nonflooded conditions. Biologyand Fertility of Soils. 35:197-203.

4. Choudhary, R., Singh, D., Singh, P., Dadarwal, R.S and Chaudhari, R. 2013. Impact of nitrogen and sulphur fertilization on yield, quality and uptake of nutrient by maize in southern Rajasthan. Annals of Plant and Soil Research. 15 (2): 118-121. 
5. Fismes, J., Vong, P.C., Guckert, A and Frossard, E. 2000. Influence of sulphur on apparent N-use efficiency, yield and quality of oilseed rape (Brassica napusL.) grown on a calcareous soil. European Journal of Agronomy. 12(2): 127-141.

6. Habtegebrial, $K$ and Singh, B.R. 2006.Effects of timing of nitrogen and sulphur fertilizers on yield, nitrogen, and sulphur contents of Tef(Eragrostistef (Zucc.) Trotter).Nutrient Cycling in Agroecosystems. 75 (1-3): 213-222.

7. Havlin, J.L., Samuel, L., Tisdale, S.L., Nelson, W.L and Beaton, J.D. 2004. Soil fertility and fertilizers. An introduction to nutrient management. 7th education.Pearson Education Inc. Singapore. p. 221

8. Mahesh, B.G. 2001. Sulphur status in Dharwad and Halyal taluks and rice response to sulphur application under rainfed situation. M. Sc. (Agri.) Thesis. University of Agricultural Science, Dharwad.

9. Malhi, S.S and Gill, K.S. 2002. Effectiveness of sulphate-S fertilization at different growth stages for yield, seed quality and S uptake of canola. Canadian Journal of Plant Sciences. 82(4): 665-674.

10. Mathew, T., Kurian, T.M., Sosamma, C and Jayakuma, G. 2003. Residual effects of sulphur nutrition on the ratoon crop of sugarcane. Sugar Techonology. 5(4): 315-316.

11. Ramanathan, S and Ramanathan, G. 1985. Effect of sulphur application on the availability of nutrients of at different stages of groundnut crop in two soils. Abstracts of proceedings of National seminar on sulphur in agriculture, Coimbattore, Tamilnadu.

12. Sakal, R., Sinha, R.B., Singh, A.P., Bhogal, N.S and Ismail, M.D. 2000. Influence of sulphur on yield and mineral nutrition of crops in maize-wheat sequence. Journal of Indian Society of Soil Science. 48 (2): 325-329.

13. Srinivasrao, Ch., Masood, Ali, Venkateshwaralu, S., Rupa, T.R., Singh, K.K., Sumanta Kundu, S and Prasad, J.V.N.S. 2010. Direct and residual effects of integrated sulphur fertilization in maize (Zea mays)-chickpea (Cicer arietinum) cropping system on typic ustochrept. Indian Journal of Agronomy. 55 (4): 259-263.

14. Takkar, P.N., Chhibba, I.M and Meht, S.K. 1989. Twenty years of coordinated research on micronutrients in soils and plants. Bull. I; Indian Institute Soil Science. Bhopal. 316.

15. Tandon, H.L.S. 1991. Sulphur research and agricultural production in India. The Sulphur Institute, USA. 140.

16. Wang, X., Wang, X., Zhang, $H$ and Jiang, W. 2014. Effects of sulphur application times on the sulphur accumulation and distribution for summer maize in fluvo-aquic soil.Advance Journal of Food Science and Technology. 6 (6): 797-801. 